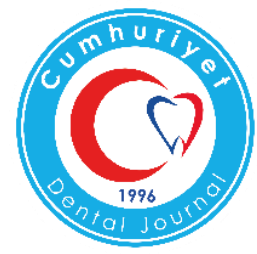

\title{
ACCURACY OF DIGITAL PANORAMIC RADIOGRAPHS ON THE VERTICAL MEASUREMENTS OF DENTAL IMPLANTS
}

\author{
Dijital Panoramik Radyografilerin Dental İmplantların Dikey Ölçümleri \\ Üzerindeki Doğruluğu
}

Burak Kerem APAYDIN ${ }^{1}$, Füsun YASAR ${ }^{2}$, Alper KIZILDAĞ $\breve{G}^{3}$, Osman Ufuk TASDEMIR ${ }^{4}$

\section{Makale Kodu/Article Code : :421453 \\ Makale Gönderilme Tarihi $\quad$ : 17.05.2018 \\ Kabul Tarihi}

\section{ABSTRACT}

Objectives: Panoramic radiography (PR) is the most commonly used technique to evaluate the dental and associated structures. The aim of this study was to determine the accuracy of panoramic radiographic images (PRIs) in planning the dental implant treatment and the magnification rate of a panoramic device for anterior, premolar and posterior regions.

Materials and Methods: Eighty-eight patients with PRIs were taken after implant surgery were included to the study. A total of 240 dental implants (53 anterior, 69 premolar, and 118 molar regions) of which actual vertical lengths were known, were re-measured on post-operative radiographic images using the scaling tools of the panoramic system to determine the magnification rate and the accuracy of PRIs. Because the data had normal distribution, the paired $t$ test was used for the statistical analysis $(\mathrm{p}<0.05)$. The magnification rates of the three regions were calculated as the ratio of the radiographically measured vertical length of the implants to the actual vertical length of the implants.

Results: A statistically significant difference was found between the actual and measured vertical length of the implants on the PRI $(p<0.05)$. However, the correlation rate was found close to 1 for all regions. The difference between the actual and measured vertical length of the implants on the PRI was $0.50 \mathrm{~mm}$ for the anterior region, $0.97 \mathrm{~mm}$ for the premolar region, and $0.83 \mathrm{~mm}$ for the molar region. The magnification rate of the panoramic system corrected by Cliniview $^{\mathrm{TM}}$ (Instrumentarium Corp., Tuusula, FINLAND) software was found around 1 for all the regions.

Conclusions: Due to their readily accessible nature and low radiation dose, PRIs can be used in implant surgery for vertical measurements with $1 \mathrm{~mm}$ confidence interval.

Keywords: Dental implant, Panoramic radiography, Radiographic examination, Radiographic magnification, Vertical measurement

\section{ÖZ}

Amaç: Panoramik radyografi (PR), dental ve ilişkili yapıları değerlendirmek için en sık kullanılan tekniktir. Bu çalışmanın amacı, dental implant tedavisinin planlanmasında panoramik radyografik görüntülerin (PRI) doğruluğunu ve anterior, premolar ve posterior bölgeler için bir panoramik cihazın büyütme oranını belirlemekti.

Gereç ve Yöntem: İmplant cerrahisi sonrası PRI'ları alınmış olan 83 hasta çalışmaya dahil edildi. Önceden dikey uzunlukları bilinen toplam 240 adet dental implant (53 anterior, 69 premolar ve 118 molar bölge), PRI'nın büyütme oranını ve doğruluğunu belirlemek için, panoramik sistemin ölçüm araçları kullanılarak ameliyat sonrası radyografik görüntüler üzerinde tekrar ölçüldü. Verilerin normal dağılıma sahip olması nedeniyle, istatistiksel analiz için eşleştirilmiş $\mathrm{t}$ testi kullanıldı ( $p<0,05)$. Üç bölgenin büyütme oranı, implantların ölçülen dikey uzunluğunun, implantların gerçek dikey uzunluğuna oranı bulunarak hesaplandı.

Bulgular: İmplantların gerçek dikey uzunluğu ve PRI'dan ölçülen dikey uzunluğu arasında istatistiksel olarak anlamlı fark bulundu ( $\mathrm{p}<0,05)$. Bununla birlikte, korelasyon oranı tüm bölgeler için 1'e yakın bulundu. İmplantların gerçek dikey uzunluğu ve PRI'den ölçülen dikey uzunluğu arasındaki fark, ön bölge için $0.50 \mathrm{~mm}$, premolar bölge için $0,97 \mathrm{~mm}$ ve molar bölge için $0,83 \mathrm{~mm}$ idi. Cliniview ${ }^{\mathrm{TM}}$ (Instrumentarium Şti., Tuusula, FINLANDIYA) yazılımı tarafından düzeltilen panoramik sistemin büyütme oranı, tüm bölgeler için 1 civarında bulundu.

Sonuçlar: PRI'lar, kolay ulaşılabilir olmaları ve düşük radyasyon dozları sayesinde, implant cerrahisi planlamasındaki dikey ölçümler için 1 mm'lik güven aralığı ile kullanılabilir.

Anahtar Kelimeler: Dental implant, Panoramik radyografi, Radyografik inceleme, Radyografik büyüme, Dikey ölçüm

\footnotetext{
${ }^{1}$ Department of Dentomaxillofacial Radiology, Faculty of Dentistry, Pamukkale University, Denizli, Turkey

${ }^{2}$ Department of Dentomaxillofacial Radiology, Faculty of Dentistry, Selcuk University, Konya, Turkey

${ }^{3}$ Department of Periodontology, Faculty of Dentistry, Pamukkale University, Denizli, Turkey

${ }^{4}$ Department of Dentomaxillofacial Surgery, Faculty of Dentistry, Pamukkale University, Denizli, Turkey
} 


\section{INTRODUCTION}

Prior to dental implant surgery, it is necessary to determine the vertical height and width of the bucco-lingual bone in which the implant will be placed, location of the nasal and maxillary sinus floor, mandibular canal site, mental foramen, the submandibular gland fossa and the location of the possible lesions in the maxilla and mandible. ${ }^{1-4}$ Determining the exact location of anatomical structures in relation to the size of dental implant increases the success rate of the implant surgery and avoids damage during surgery. This can only be possible with proper and careful radiological examination. ${ }^{2,5}$

To date, radiographic methods such as panoramic, periapical and occlusal radiographs, conventional tomography (T), computed tomography (CT) and cone beam computed tomography (CBCT) have been used for the pre-surgical implant planning. Clinicians should determine the optimal imaging method for every patient. ${ }^{6-8}$ Naturally, choosing a radiographic method that provides sufficient diagnostic information for treatment planning with least possible radiation dose (ALARA principle: as low as reasonably achievable) should be the goal. ${ }^{9}$

Determination of the bucco-lingual width of edentulous region needs cross-sectional images that can be obtained from T, CT, and CBCT. ${ }^{9}$ Recently, the use of CT and CBCT has been increased. ${ }^{1}$ Studies showed that Ts and CTs are more reliable than intraoral and panoramic radiographs. ${ }^{10,11}$ However, expensive imaging devices have several disadvantages including having high radiation dose, formation of CT streak artifacts in the presence of pins or metal restorations, and inability of the patient to move during long exposure time. In addition, CBCT performs highly to visualize anatomical structures, periodontal and periapical bone defects, and evaluation of the implant sites. , $^{1,9}$

Non-uniform magnification rate causes dimensional measurements to be restricted in
PRDs. ${ }^{4,5,12}$ Nevertheless, PR is an easily accessible and widely used technique. It provides imaging of both maxillary and mandibular dental arches along with their neighboring tissues; residual dental roots, apical or bone lesions and distance between remaining teeth with a low radiation dose in a short time. ${ }^{5}$, ${ }^{13}$ Studies have reported that PRIs are reliable to assess the posterior mandibular bone height when the patient is appropriately positioned, and cross- sectional imaging is not necessary for each patient. ${ }^{1,14-17}$ Frei et al. ${ }^{18}$ stated that PR provided sufficient information for implant length selection. Sakakura et al. ${ }^{7}$ reported that the majority of dentists ( $82.6 \%$ ) chose PR in the dental implant planning because of the broad coverage and economical reasons. However, having image distortion, and not giving the width of alveolar bone and the cross-sectional dimension of the bone are shortcomings of PRIs. The width of alveolar bone can be determined by various clinical tests. The width of alveolar ridge, the presence and size of lingual undercuts can be examined manually in an edentulous region. If necessary, an impression can be made for an accurate evaluation. ${ }^{1} \quad \mathrm{~A}$ well-trained surgeon can evaluate the width of the posterior mandible with his experience and decide whether it is suitable for implant placement. However, muscles and connective tissues can affect the clinical appearance. ${ }^{18}$

Vazquez et al. ${ }^{14}$ have studied the magnification rate of the Scanora ${ }^{\circledR}$ unit (Soredex Orion Corp., Helsinki, Finland) and they recommended that the magnification rate of other panoramic devices should be verified. Some authors have reported that the reference objects of known dimensions should be used to precisely determine the magnification rate. ${ }^{18,19}$

The purpose of this study was to determine the reliability of PR in vertical bone measurements prior to dental implant surgery and to determine the magnification rate of the Instrumentarium

Dental $^{\mathrm{TM}}$ 


\section{ORTHOPANTOMOGRAPH ${ }^{\mathrm{TM}}$ OP200D}

(Instrumentarium Corp., Tuusula, FINLAND) (OP200D) instrument for anterior, posterior and molar regions. The null hypothesis of this study was 'there is no statistically significant difference between actual and measured vertical length of the implant on the PRI'.

\section{MATERIALS AND METHODS}

A letter confirming ethical approval for the study was obtained from Pamukkale University, Faculty of Medicine, Ethics Committee (number: 60116787-020/32012). Eighty-eight patients with no pathological lesions or bone disease who had undergone implant surgery at the Pamukkale University, Faculty of Dentistry (Denizli, Turkey) with a clear PRI taken in the correct position after the implant surgery were included in the study. PRIs were randomly chosen from the patient archive of the Dentomaxillofacial Radiology Clinic. None of the PRIs were obtained specifically for this study. All radiographs were taken by using the same panoramic machine (OP 200D) and by the same x-ray technician (S.C.) who used a standard exposure protocol $(66 \mathrm{kV} / 10 \mathrm{~mA} / 16 \mathrm{~s})$. All patients were positioned using a bite block according to the manufacturer's instructions during the exposure of PRIs. The 240 dental implants (53 anterior, 69 premolar and 118 molar region), which dimensions were previously known, were measured on the postsurgical PRIs by a dentomaxillofacial radiologist (BK. A. who didn't participate in the surgery) with the scaling tool of the panoramic system (Figure 1).

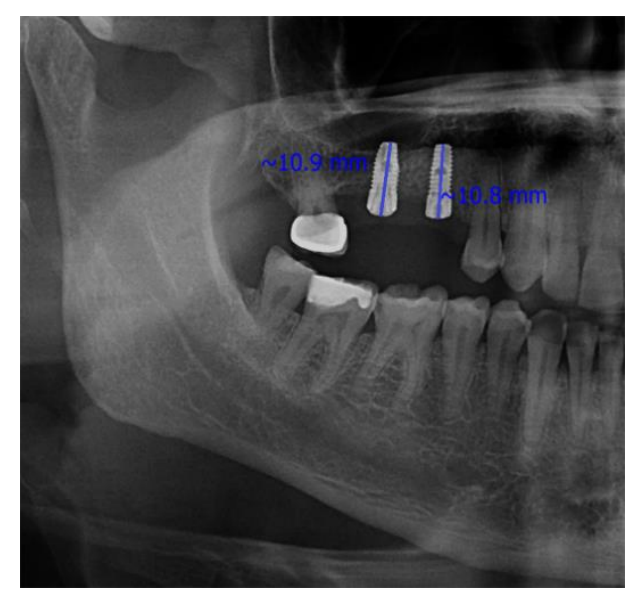

Using postsurgical PRIs, the magnification rate was determined for each region by the following formula:

Measured length of the implant on PRI /Actual length of the implant

Statistical data analysis was performed using a computer software (SPSS 21.0 version IBM Corp., Chicago, IL, USA). The KolmogorovSmirnov test was performed to determine whether the data showed a normal distribution. The paired $t$ test was used to analyze the difference between the measured and actual vertical length of the implants $(\mathrm{p}<0.05)$. Pearson correlation analysis was used to determine the correlation between the actual length and the measured length of the implant $(\mathrm{p}<0.05)$.

\section{RESULTS}

A statistically significant difference was found between the measured and actual size of the implants in all regions $(\mathrm{p}<0.05)$. The difference between the actual size and measured size of the implants were $0.50 \mathrm{~mm}$ in the anterior region, $0.97 \mathrm{~mm}$ in the premolar region and $0.83 \mathrm{~mm}$ in the molar region (Table 1).

Table 1. The relationship between the actual size of the implants and the measured size on the PRI of the implants according to the regions $(\mathrm{M} \pm \mathrm{SD})$.

\begin{tabular}{|c|c|c|c|c|c|c|}
\hline Region & $\begin{array}{c}\text { Measured } \\
\text { size } \\
(\mathbf{M} \pm \text { SD) }\end{array}$ & $\begin{array}{c}\text { Actual size } \\
(\mathbf{M} \pm \text { SD) }\end{array}$ & $\mathbf{n}$ & $\begin{array}{c}\text { Averages } \\
\text { of } \\
\text { differences }\end{array}$ & $\mathbf{t}$ & $\mathbf{p}$ \\
\hline Anterior & $11.89 \pm 1.55$ & $11.84 \pm 1.55$ & 53 & $0.50 \pm 0.12$ & -2.97 & 0.005 \\
\hline Premolar & $11.12 \pm 1.46$ & $11.02 \pm 1.44$ & 69 & $0.97 \pm 0.12$ & -6.40 & $<0.001$ \\
\hline Molar & $10.40 \pm 1.53$ & $10.32 \pm 1.50$ & 118 & $0.83 \pm 0.12$ & -7.47 & $<0.001$ \\
\hline
\end{tabular}


The correlation coefficient was close to 1 for all regions (Table 2).

Table 2. Pearson correlation between actual and measured values according to the regions.

\begin{tabular}{|c|c|c|c|}
\hline Variables & $\mathbf{n}$ & $\begin{array}{c}\text { Correlation } \\
\text { coefficient }\end{array}$ & $\mathbf{p}$ \\
\hline $\begin{array}{c}\text { Anterior Region Actual Length\&Anterior } \\
\text { Region Measured Length }\end{array}$ & 53 & 0.997 & $<0.001$ \\
\hline $\begin{array}{c}\text { Premolar Region Actual Length \&Premolar } \\
\text { Region Measured Length }\end{array}$ & 69 & 0.996 & $<0.001$ \\
\hline $\begin{array}{c}\text { Molar Region Actual Length \&Molar Region } \\
\text { Measured Length }\end{array}$ & 118 & 0.997 & $<0.001$ \\
\hline
\end{tabular}

The magnification rates was close to 1 for all regions (Table 3).

Table 3. Magnification rates according to the regions.

\begin{tabular}{|c|c|}
\hline Region of implant & Magnification rate \\
\hline Anterior region & 1.004 (ranging from 0.98 to 1.02) \\
\hline Premolar region & 1.008 (ranging from 0.98 to 1.03) \\
\hline Molar region & 1.007 (ranging from 0.98 to 1.03 ) \\
\hline
\end{tabular}

In the user manual of OP200D, the magnification rate is specified as 1.3. However the manual also states that Cliniview ${ }^{\mathrm{TM}}$ software automatically corrects the growth rate. In this study values corrected with Cliniview $^{\mathrm{TM}}$ software were accounted.

\section{DISCUSSION}

The choice of implant length and width is generally determined by the volume and density of the existing alveolar ridge, the location of adjacent teeth and vital anatomical structures, the type of prosthesis, and the treatment protocol. Theoretically, longer and wider implants should be preferred in order to resist the loaded forces and avoid fracture risk after prosthetic treatment. ${ }^{9}$ On the other hand, studies involving new implant designs/surfaces have reported that the failure rate of short and long implants is comparable and there is no relationship between implant diameter and survival ratio. ${ }^{2,9,20}$ On the contrary, it has also been argued that cases with fresh sockets require larger and/or longer implants to ensure primary implant stability and to reduce the distance between implant and bone socket walls. ${ }^{21}$ However, Vazquez et al. pointed out that protecting the mandibular canal was always their priority. They reported that the use of short implants does not jeopardize the long-term implant success rate and may reduce nerve injury risk associated with implant placement in the posterior segment of the mandible, especially when the mandibular canal is difficult to localize on the radiograph. ${ }^{22}$

Schropp et al. ${ }^{9}$ argued that the choice of implant size was greatly influenced by the radiographic technique used for presurgical treatment planning. They also reported that the lack of cross-sectional information may lead to the use of shorter and narrower implant sizes. ${ }^{23}$ However, they reported that the implants planned with cross-sectional imaging could not be considered more successful. In addition, they reported that there was no consensus on the need for cross-sectional imaging when a panoramic radiograph was already present. $^{9}$

The information provided by crosssectional images are valuable in giving detailed and 1:1 images, detecting lingual undercuts in the posterior zone of the mandible. If lingual perforation occurs during implant operation, this can result in life-threatening bleeding and/or airway obstruction due to the impact on the large arteries of the mandibular base. ${ }^{18}$ In order to avoid the complications associated with mandibular canal, it is recommended that the distance between the lower limit of the implant and the mandibular canal should be at least $2 \mathrm{~mm}$ taking the magnification rate of the $\mathrm{PR}$ in consideration. $6,9,14$ Although CT and CBCT images are known to give detailed and 1:1 rearranged images, it is recommended that the distance between the implant and mandibular canal should be at least $1.7 \mathrm{~mm}$. This value is similar to the recommended value for PR. ${ }^{15}$ CBCT may be preferred when 3D imaging is required, but effective radiation dose of CBCT is much higher and more expensive than traditional dental radiographs. ${ }^{1,9}$ For these reasons; we preferred to plan this study on PR.

PRIs tend to underestimate the distance between the alveolar crest and the upper border 
of the mandibular canal. ${ }^{24}$ Underestimation of this distance is less harmful than overestimation. In the case of an overestimation, a long implant may damage the nerve. ${ }^{15}$ Frie et al. ${ }^{18}$ found a magnification rate of $1.27 \pm 0.01$. They also showed that the height of the vertical bone measured by spiral tomogram was $1 \mathrm{~mm}$ longer than the height of the bone measured by PR. Because spiral tomograms tend to overestimate the distance, assessment of the vertical bone height can be risky if measured only by spiral CT. ${ }^{22}$

There are also studies reporting that PR shows overestimation in posterior mandibular measurements. ${ }^{4,5}$ Rockenbach et al. ${ }^{4}$ estimated that PR overestimated linear measurements on the mandibular field. Nevertheless, they stated that PR and linear tomography of implant site measurements can be used safely with a safety margin of $2 \mathrm{~mm}$.

The accuracy of bone measurements on PR has been questioned because of the magnification and distortion (Table 4). ${ }^{14,25}$

Table 4. Magnification rates found with different PR devices.

\begin{tabular}{|c|c|c|}
\hline Author (s) & Device / Company & Magnification rate \\
\hline \multirow{2}{*}{ Kim et al [1] } & \multirow{2}{*}{$\begin{array}{l}\text { Panoramic Radiograph/ Orthopantomograph }{ }^{\otimes} / \\
\text { Instrumentarium }\end{array}$} & $\begin{array}{l}1.26 \text { (mandibular premolar } \\
\text { region) }\end{array}$ \\
\hline & & $\begin{array}{c}1.25 \text { (mandibular molar } \\
\text { region) }\end{array}$ \\
\hline \multirow{2}{*}{ Park et al [6] } & \multirow{2}{*}{ Panoramic Radiograph/Cranex ${ }^{\circledast} /$ Soredex } & $\begin{array}{l}1.31 \text { (mandibular premolar } \\
\text { region) }\end{array}$ \\
\hline & & $\begin{array}{c}1.27 \text { (mandibular molar } \\
\text { region) }\end{array}$ \\
\hline \multirow{2}{*}{ Yim et al $[8]$} & Panoramic Radiograph/ Promax / Planmeca & $\begin{array}{l}1.171 \pm 0.057 \text { (not depending } \\
\text { on region) }\end{array}$ \\
\hline & Panoramic Radiograph/Ortho Stage / Asahi & $\begin{array}{l}1.270 \pm 0.051 \text { (not depending } \\
\text { on region) }\end{array}$ \\
\hline \multirow{2}{*}{$\begin{array}{l}\text { Vazquez et al } \\
{[14]}\end{array}$} & \multirow{2}{*}{ Panoramic Radiograph/ Scanora $^{\mathbb{Q}} /$ Soredex } & $1.28 \pm 0.01$ (premolar region) \\
\hline & & $1.27 \pm 0.01$ (molar region) \\
\hline \multirow{2}{*}{ Frie et al [18] } & Panoramic Radiograph/Cranex Tome ${ }^{\mathbb{} /} /$ Soredex & $\begin{array}{l}1.27 \pm 0.01 \text { (not depending on } \\
\text { region) }\end{array}$ \\
\hline & Spiral Tomogram & $\begin{array}{c}1.52 \pm 0.01 \text { (not depending on } \\
\text { region) }\end{array}$ \\
\hline
\end{tabular}

Knowing the correct magnification rate will allow more precise selection of implant size. A previous study on imaging procedures of implant treatment has suggested that the correct magnification rate should be determined for the calibration of the region to which the implant is to be applied. ${ }^{2,9}$ For this reason, we aimed to determine the correct magnification rate for the OP200D in this study.

It has also been reported that the use of bite blocks reduces positional errors while PRIs are taken. ${ }^{5,6,14}$ Therefore, in our study the patients used bite blocks and their positioning was done according to the manufacturer's instructions.

No single implant trademark was used in this study. In addition, grouping of maxilla and mandible was not performed in implant measurements. These are the shortcomings of this study.

\section{CONCLUSIONS}

Within the limitations of this study, following conclusions can be drawn; the magnification rate of OP200D is close to 1 and it gives errors less than $1 \mathrm{~mm}$ in vertical measurements made with Cliniview ${ }^{\mathrm{TM}}$ software. Therefore, except the cases where the location of the mandibular canal and lingual undercuts in the posterior region of the mandible cannot be clearly detected and cross sectional images are required; PRs with known magnification rates can be used with easy access, low radiation dose and low cost, in the vertical measurements with a $1 \mathrm{~mm}$ confidence interval.

\section{REFERENCES}

1. Kim YK, Park JY, Kim SG, Kim JS, Kim JD. Magnification rate of digital panoramic radiographs and its effectiveness for preoperative assessment of dental implants. Dentomaxillofac Radiol 2011;40:76-83.

2. Schropp L, Stavropoulos A, Gotfredsen E, Wenzel A. Calibration of radiographs by a reference metal ball affects preoperative selection of implant size. Clin Oral Investig 2009;13:375-381.

3. Mehra A, Pai KM. Evaluation of dimensional accuracy of panoramic crosssectional tomography, its ability to identify the inferior alveolar canal, and its impact on estimation of appropriate implant dimensions in the mandibular posterior region. Clin Implant Dent Relat Res 2012;14:100-111.

4. Rockenbach MI, Sampaio MC, Costa LJ, Costa NP. Evaluation of mandibular implant sites: correlation between panoramic and linear tomography. Braz Dent J 2003;14:209-213. 
5. Haghnegahdar A, Bronoosh P. Accuracy of linear vertical measurements in posterior mandible on panoramic view. Dent Res J (Isfahan) 2013;10:220-224.

6. Park JB. The evaluation of digital panoramic radiographs taken for implant dentistry in the daily practice. Med Oral Patol Oral Cir Bucal 2010;15:663-666.

7. Sakakura CE, Morais JA, Loffredo LC, Scaf G. A survey of radiographic prescription in dental implant assessment. Dentomaxillofac Radiol 2003;32:397-400.

8. Yim JH, Ryu DM, Lee BS, Kwon YD. Analysis of digitalized panorama and cone beam computed tomographic image distortion for the diagnosis of dental implant surgery. J Craniofac Surg 2011;22:669-673.

9. Schropp L, Stavropoulos A, Gotfredsen E, Wenzel A. Comparison of panoramic and conventional cross-sectional tomography for preoperative selection of implant size. Clin Oral Implants Res 2011;22:424-429.

10.Lindh C, Petersson A, Klinge B. Visualisation of the mandibular canal by different radiographic techniques. Clin Oral Implants Res 1992;3:90-97.

11. Sonick M. A comparison of the accuracy of periapical, panoramic, and computerized tomographic radiographs in locating the mandibular canal. Int $\mathbf{J}$ Oral Maxillofac Implants 1994;9:455-460.

12.Kitai N, Mukai Y, Murabayashi M, Kawabata A, Washino K, Matsuoka M, Shimizu I, Katsumata A. Measurement accuracy with a new dental panoramic radiographic technique based on tomosynthesis. Angle Orthod 2013;83:117-126.

13. Nikneshan S, Sharafi $M$, Emadi $N$. Evaluation of the accuracy of linear and angular measurements on panoramic radiographs taken at different positions. Imaging Sci Dent 2013;43:191-196.

14. Vazquez L, Nizam Al Din $\mathrm{Y}$, Christoph Belser U, Combescure C, Bernard JP. Reliability of the vertical magnification factor on panoramic radiographs: clinical implications for posterior mandibular implants. Clin Oral Implants Res 2011;22:1420-1425.

15. Vazquez L, Nizamaldin Y, Combescure C, Nedir R, Bischof M, Dohan Ehrenfest DM, Carrel JP, Belser UC. Accuracy of vertical height measurements on direct digital panoramic radiographs using posterior mandibular implants and metal balls as reference objects. Dentomaxillofac Radiol 2013;42:20110429.

16. $\mathrm{Tal} \mathrm{H}$, Moses $\mathrm{O}$. A comparison of panoramic radiography with computed tomography in the planning of implant surgery. Dentomaxillofac Radiol 1991;20:40-42.

17. Volohansky A, Cleaton-Jones P, Drummond $S$, Bönecker $M$. Technique for linear measurement on panoramic and periapical radiographs: a pilot study. Quintessence Int 2006;37:191-197.

18. Frei C, Buser D, Dula K. Study on the necessity for cross-section imaging of the posterior mandible for treatment planning of standard cases in implant dentistry. Clin Oral Implants Res 2004;15:490-497.

19. Stramotas S, Geenty JP, Petocz P, Darendeliler MA. Accuracy of linear and angular measurements on panoramic radiographs taken at various positions in vitro. Eur J Orthod 2002;24:43-52.

20.Renouard F, Nisand D. Impact of implant length and diameter on survival rates. Clin Oral Implants Res 2006;17:35-51.

21.Degidi M, Piattelli A, Iezzi G, Carinci F. Do longer implants improve clinical outcome in immediate loading? Int $\mathrm{J}$ Oral and Maxillofac Surg 2007;36:1172-1176.

22. Vazquez L, Saulacic N, Belser U, Bernard JP. Efficacy of panoramic radiographs in the preoperative planning of posterior mandibular implants: a prospective clinical study of 1527 consecutively treated patients. Clin Oral Implants Res 2008;19:81-85.

23.Schropp L, Wenzel A, Kostopoulos L. Impact of conventional tomography on prediction of the appropriate implant size. Oral Surg Oral Med Oral Pathol Oral Radiol Endod 2001;92:458-463. 
24. Lindh C, Petersson A, Klinge B.
Measurements of distances related to the mandibular canal in radiographs. Clin Oral Implants Res 1995;6:96-103.

25. Yassaei S, Ezoddini-Ardakani F, Ostovar N. Predicting the actual length of premolar teeth on the basis of panoramic radiology. Indian J Dent Res 2010;21:468-473.

\section{Corresponding Author}

Burak Kerem Apaydın

Pamukkale University

Faculty of Dentistry,

Department of Dentomaxillofacial Radiology,

Denizli, Turkey

Tel : +902582964225

Fax : +902582961763

E-mail : drkeremapaydin@gmail.com

Conflict of interest: The authors declare that they have no conflict of interest. 